\title{
REAKSI PASAR MODAL TERHADAP PENGUMUMAN PAKET KEBIJAKAN EKONOMI JILID 1, 5, 7, 11 DAN 13
}

\author{
Adelia Nandira Maharani \\ adelia.nandira@gmail.com \\ Irni Yunita \\ Fakultas Ekonomi dan Bisnis, Universitas Telkom
}

diterima: 16/1/2018; direvisi: 10/9/2018; diterbitkan: 29/10/2018

\begin{abstract}
The purpose of this research is to analize market reaction to the 1 st, 5 th, 7 th, 11 th and 13 th economic policy packages. This research uses event study approach. Its measurement of market reaction would be seen from the difference of Abnormal Return and Trading Volume Activity before and after the events. Sample of this research was selected through purposive sampling techniques which include 12 firms. The data analysis used paired sample of t-test. These results indicated that there is no difference in abnormal returns before and after 1st, 5th, 7th and 13th economic policy packages announcement. There is a difference in abnormal returns before and after 11th economic policy packages announcement. There is no difference in trading volume activity before and after 1st, 5th, 7 th, 11 th and 13th economic policy packages announcement. Market reacts fast and protracted to the event which indicate that market is not efficient in semi strong-form.
\end{abstract}

Keywords: abnormal return; trading volume activity; event study; economic policy packages

\begin{abstract}
Abstrak
Penelitian ini bertujuan untuk menganalisis reaksi pasar terhadap pengumuman paket kebijakan ekonomi jilid 1, 5, 7, 11 dan 13. Penelitian ini menggunakan pendekatan event study dengan pengukuran dilihat dari perbedaan abnormal return dan trading volume activity sebelum dan sesudah peristiwa. Sampel penelitian sebanyak 12 perusahaan yang dipilih dengan teknik purposive sampling. Analisis data menggunakan uji paired sample t-test. Hasil penelitian menunjukkan tidak terdapat perbedaan abnormal return sebelum dan sesudah peristiwa pengumuman paket kebijakan ekonomi jilid 1, 5,7 dan 13 dan terjadi perbedaan abnormal return sebelum dan sesudah peristiwa pengumuman paket kebijakan ekonomi jilid 11. Tidak terdapat perbedaan trading volume activity sebelum dan sesudah peristiwa pengumuman paket kebijakan ekonomi jilid 1, 5, 7, 11 dan 13 . Kemudian pasar bereaksi secara cepat dan berlarut-larut sehingga hal tersebut berindikasi bahwa pasar sedang dalam keadaan tidak efisien secara semi strong-form.
\end{abstract}

Kata Kunci : return tidak normal; trading volume activity; studi peristiwa; paket kebijakan ekonomi 


\section{PENDAHULUAN}

Perlambatan ekonomi dunia yang terjadi pada tahun 2015 berdampak pada perekonomian di berbagai negara. Salah satu negara yang mengalami dampaknya hingga mendominasi perlambatan ekonomi di kawasan Asia adalah Tiongkok. Perlambatan ekonomi mengakibatkan terjadinya devaluasi Tiongkok yang mempengaruhi indikator IHSG dan nilai kurs valuta asing di Indonesia. Sehari setelah pengumuman devaluasi tersebut IHSG turun hingga 2,7\% menjadi 4.622,6 volume perdagangan berada pada besaran Rp 3,8 triliun bahkan seluruh sektor saham memiliki catatan kinerja negatif (Hartono, 2017:134).

Hal tersebut membuat pemerintah Indonesia melakukan tindakan untuk menstabilkan kondisi ekonomi Indonesia karena saat ini investasi saham merupakan salah satu jenis investasi yang saat ini semakin diminati masyarakat. Hal tersebut terbukti dengan meningkatnya jumlah investor pasar modal di Indonesia menurut data operasional BEI dan data Kustodian Sentral Efek Indonesia (KSEI). Jumlah investor meningkat pada periode 2015-2016 sebanyak 23,47\% dengan peningkatan Single Investor Identification (SID) dari 434.107 menjadi 535.994 SID atau meningkat sebanyak 101.887 SID. Investor baru di pasar modal ini menunjukkan peningkatan dari periode sebelumnya yaitu periode tahun 2014-2015 yang tercatat sebesar 18,83\% (Abbas, 2017).

Salah satu tindakan yang dilakukan pemerintah adalah penerbitan paket kebijakan ekonomi berjilid. Hingga Agustus 2017 tercatat sudah ada 16 paket kebijakan ekonomi yang pemerintah terbitkan (Deny, 2017). Paket kebijakan ekonomi ini sendiri memiliki dampak yang cukup signifikan bagi pasar modal Indonesia, sebab dari pergerakan IHSG selama penerbitan paket kebijakan ekonomi ini menunjukkan peningkatan secara kontinu seperti yang terlihat pada Gambar 1.

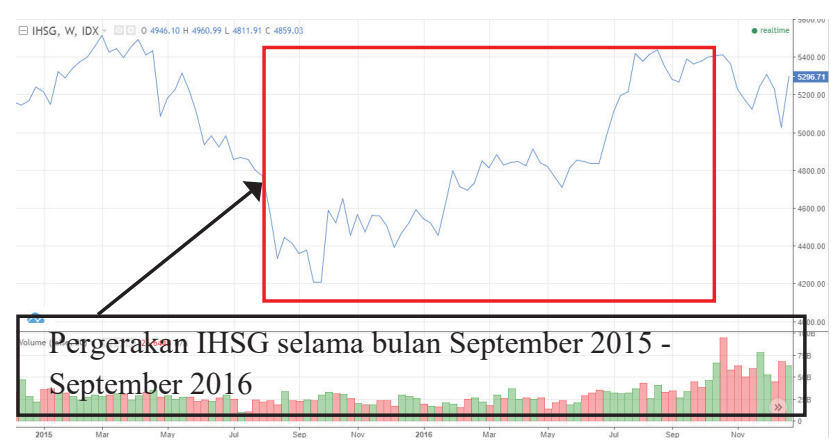

Sumber: https://www.poems.co.id/ (2015)

Gambar 1. Pergerakan IHSG selama periode paket kebijakan ekonomi

Objek penelitian dari penelitian ini adalah perusahaan-perusahaan yang listing di Bursa Efek Indonesia tercatat sudah ada 555 perusahaan yang terdaftar di Bursa Efek Indonesia. Bursa Efek Indonesia merupakan perseroan swasta yang memberikan jasa fasilitas perdagangan sekuritas yang didalamnya terdapat indeks yang berperan sebagai indikator pergerakan sekuritas sehari-hari (Hartono, 2017:166). Khususnya objek dari penelitian ini adalah perusahaan yang terdapat di salah satu indeks yang ada di Bursa Efek Indonesia, yaitu indeks-indeks IDX Sektoral. Indeks Sektoral property, real estate, and building construction (Hartono, 2017:172)

Selama periode September tahun 2015 hingga September tahun 2016 Presiden Joko Widodo telah menerbitkan 13 paket kebijakan ekonomi. Paket kebijakan ekonomi tersebut menargetkan ke berbagai sektor, salah satunya sektor property, real estate and building construction yang menjadi objek penelitian ini yang terdapat pada paket kebijakan jilid 1, 5, 7, 11 dan 13 (Tabel 1).

Tabel 1. Isi Paket Kebijakan Ekonomi Terkait Sektor Property, Real Estate and Building Construction

\begin{tabular}{|c|c|c|}
\hline $\begin{array}{c}\text { Paket } \\
\text { Kebijakan } \\
\text { Ekonomi } \\
\text { Jilid }\end{array}$ & $\begin{array}{c}\text { Tanggal } \\
\text { Penerbitan }\end{array}$ & Paket Kebijakan Ekonomi \\
\hline 1 & $\begin{array}{l}9 \text { September } \\
2015\end{array}$ & $\begin{array}{l}\text { Meningkatkan investasi di sektor } \\
\text { properti. }\end{array}$ \\
\hline 5 & $\begin{array}{l}22 \text { Oktober } \\
2015\end{array}$ & $\begin{array}{l}\text { Menghilangkan pajak berganda } \\
\text { dana investasi real estate, property } \\
\text { dan infrastruktur. }\end{array}$ \\
\hline 7 & $\begin{array}{l}7 \text { Desember } \\
2015\end{array}$ & $\begin{array}{l}\text { Percepatan penerbitan sertifikat } \\
\text { tanah. }\end{array}$ \\
\hline 11 & $\begin{array}{l}30 \text { Maret } \\
2016\end{array}$ & $\begin{array}{l}\text { Menerbitkan Dana Investasi Real } \\
\text { Estate (DIRE) dengan biaya yang } \\
\text { relatif rendah untuk meningkatkan } \\
\text { efisiensi dalam penyediaan } \\
\text { dana investasi jangka panjang, } \\
\text { untuk menunjang percepatan } \\
\text { pembangunan infrastruktur dan } \\
\text { perumahan sesuai Program Jangka } \\
\text { Menengah Nasional Tahun 2015- } \\
2019 \text {. }\end{array}$ \\
\hline 13 & $\begin{array}{l}10 \text { September } \\
2016\end{array}$ & $\begin{array}{l}\text { Percepatan penyediaan perumahan } \\
\text { untuk masyarakat berpenghasilan } \\
\text { rendah. }\end{array}$ \\
\hline
\end{tabular}

Sumber: Hartono (2017)

Informasi dalam pasar modal didapat dari berbagai sumber, baik dari internal perusahaan seperti corporate action ataupun dari eksternal perusahaan. Paket kebijakan ekonomi berjilid merupakan salah satu contoh informasi eksternal yang mampu mempengaruhi harga dari sekuritas yang termasuk dalam kategori pengumuman-pengumuman yang berhubungan dengan pemerintah (Government-related Announcements) 
(Hartono, 2017:609). Apabila informasi peristiwa yang terjadi relevan maka yang diharapkan adalah adanya reaksi pasar yaitu perubahan harga saham. Kemudian apabila ada kecepatan reaksi dari perubahan harga saham, hal tersebut dapat menggambarkan tingkat efisiensi pasar modal (Putri, 2016).

Perubahan indeks harga saham terjadi akibat diterbitkannya paket kebijakan ekonomi, salah satu contohnya adalah indeks harga saham sektoral pada sektor property, real estate and building construction. Sehari setelah penerbitan paket kebijakan ekonomi jilid 5 pada tanggal 22 Oktober 2015 berdasarkan FinanceDetik IHSG mampu bertahan di zona hijau dan menutup perdagangan akhir pekan dengan kenaikan 68,584 poin $(1,50 \%)$ ke level $4.653,146$. Hampir seluruh indeks sektoral menguat dan penguatan tertinggi terjadi pada sektor aneka industri dan konstruksi (Aliya, 2015).

Salah satu contohnya terjadi pada indeks harga saham pada property, real estate and building construction periode $\mathrm{t}+1$ (23 Oktober 2015) dan $\mathrm{t}+2$ (26 Oktober 2015) dari tanggal penerbitan paket kebijakan ekonomi jilid 5 pada tanggal 22 Oktober 2015 yang mengalami kenaikan harga saham yang cukup signifikan seperti yang ditunjukkan Gambar 2 .

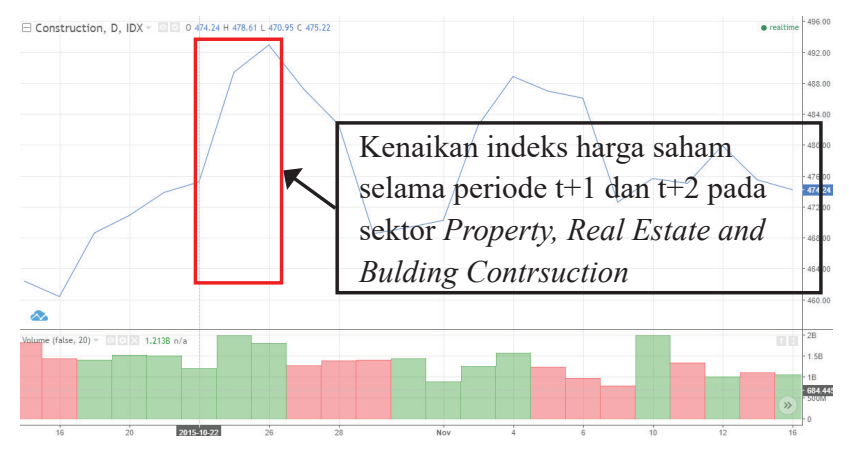

Sumber: https://www.poems.co.id/ (2015)

Gambar 2. Kenaikan indeks harga saham pada Sektor Property, Real Estate and Building Construction

Fama (1970) menjelaskan secara singkat bahwa hipotesis pasar yang efisien adalah harga sekuritas yang mencerminkan secara penuh semua informasi yang tersedia. Apabila pasar efisien telah terbentuk dalam pasar modal di Indonesia, maka hal tersebut akan memberikan keuntungan bagi berbagai pihak seperti emiten atau perusahaan yang terdaftar di pasar modal maupun bagi investor. Apabila pasar sudah efisien informasi yang didapat akan lebih akurat dan merata. Sehingga tidak akan terjadi abnormal return yang di kemukakan oleh Samsul (2006) yaitu selisih antara return yang sesungguhnya dengan return yang diharapkan oleh investor.

Pengujian efisiensi pasar bentuk setengah kuat dengan melihat abnormal return yang terjadi. Dampak dari pasar modal yang telah efisien adalah akan sangat sulit bagi para investor mendapatkan tingkat abnormal return (selisih lebih antara return sesungguhnya dengan return normal). Peninjauan yang dapat dilakukan pada pasar bentuk setengah kuat dari segi informasi yang tersedia. Ada dua faktor yang ditekankan pada pengujian pasar bentuk ini yaitu abnormal return dan kecepatan reaksi (Hartono, 2017:649).

Selain menggunakan abnormal return, reaksi pasar dapat dilihat dengan menggunakan parameter pergerakan trading volume activity. Apabila ada peningkatan volume perdagangan hal tersebut menunjukkan dua arti, yaitu jika volume meningkat karena permintaan maka peristiwa yang terjadi merupakan berita baik (good news). Kemudian apabila peningkatan volume perdagangan karena penjualan, maka peristiwa tersebut merupakan berita buruk (bad news) (Wardani, 2004).

Menentukan pasar modal yang efisiensi tidak terlepas dari informasi-informasi, tidak hanya informasi yang lama tetapi juga informasi yang sedang dipublikasikan termasuk informasi privat akan berpengaruh (Hartono, 2017:606). Oleh sebab itu dilakukanlah berbagai penelitian mengenai informasi eksternal perusahaan seperti pengumuman-pengumuman yang berkaitan dengan pemerintah contohnya pengumuan pemilu legislatif, peritiwa politik di parlemen, dan lain sebagainya. Penelitian terdahulu dilakukan oleh I Made dan Ida Bagus (2015) menunjukkan tidak terdapat perbedaan abnormal return yang signifikan sebelum dan sesudah pengumuman peristiwa pemilu legislatif tahun 2014. Sama dengan penelitian oleh Nurbaity dan Syarifah (2017), hasil dari pengujian reaksi pasar terhadap peristiwa pengumuman paket kebijakan ekonomi jilid II menggunakan one sample t-test pasar bereaksi sebelum terjadinya peristiwa tetapi tidak bereaksi pada saat dan sesudah peristiwa. Sedangkan pada pengujian paired sample t-test AAR dan ATVA tidak menunjukkan perbedaan yang signifikan, sehingga pasar di Indonesia efisien dalam bentuk semi-strong form.

Namun hasil yang didapat dari penelitian terdahulu menunjukkan hasil yang berbeda-beda. Penelitian oleh Gusti, Dewa dan Ni Ketut (2017) menunjukkan terdapat reaksi pasar atas pengumuman paket kebijakan ekonomi X tentang Daftar Negatif Investasi (DNI). Kemudian penelitian oleh Rica, Wiwik dan Fitrini mengenai pergantian menteri keuangan RI tahun 2010 terhadap abnormal return menunjukkan adanya perbedaan Average Abnormal return (AAR) yang signifikan sebelum dan sesudah peristiwa tersebut.

Penelitian mengenai abnormal return dan trading volume activity juga dilakukan dengan informasi ekstenal lainnya sebagai fenomena yang dijadikan dasar penelitian. Informasi-informasi tersebut memberikan hasil yang berbeda-beda, seperti penelitian oleh LiangMui et. al. (2016) yang menunjukkan hasil pengumuman kejahatan kerah putih memiliki abnormal return yang negatif, dan pasar tidak bereaksi secara efisien terhadap informasi yang diumumkan. 
Berbeda dengan fenomena informasi lain yang dilakukan oleh Mian et. al. (2012) yang menunjukkan peristiwa politik berpengaruh pada return KSE dengan kondisi 7 peristiwa memiliki pengaruh yang signifikan selama periode singkat.

\section{METODE}

Penelitian ini termasuk ke dalam jenis penelitian deskriptif komparatif, menggunakan studi peristiwa. Menurut Rica et. al. (2012) studi peristiwa merupakan metodologi yang digunakan untuk mempelajari reaksi pasar suatu peristiwa yang informasinya dipublikasikan sebagai suatu pengumuman. Jika pengumuman tersebut mengandung informasi maka pasar diharapkan akan bereaksi pada waktu pengumuman tersebut diterima pasar. Studi peristiwa ini juga dapat digunakan sebagai penguji kandungan informasi dari suatu pengumuman corporate action maupun pengumuman eksternal yang terjadi. Peristiwa dalam penelitian yang akan diuji kandungan informasinya adalah peristiwa penerbitan paket kebijakan ekonomi jilid 1, 5, 7, 11 dan 13 terhadap abnormal return saham perusahaanperusahaan sektor property, real estate, and building construction yang terdaftar di Bursa Efek Indonesia. Secara keseluruhan karakteristik penelitian ini terdapat pada Tabel 2.

Tabel 2. Karakteristik Penelitian

\begin{tabular}{llc}
\hline No & Karakteristik Penelitian & Jenis \\
\hline 1 & Berdasarkan metode & Kuantitatif \\
2 & Berdasarkan tujuan & Deskriptif \\
3 & Berdasarkan tipe penyelidikan & Komparatif \\
4 & Berdasarkan keterlibatan peneliti & Tidak mengintervensi data \\
5 & Berdasarkan unit analisis & Organisasi \\
6 & Berdasarkan waktu pelaksanaan & Time series \\
\hline
\end{tabular}

Variabel penelitian merupakan suatu atribut atau nilai dari orang, objek, atau kegiatan yang mempunyai variasi antara satu orang dengan yang lain atau satu objek dengan objek yang lain (Sugiyono 2015: 38). Penelitian yang berbasis event study ini, variabel yang diteliti adalah abnormal return dan trading volume activity saham perusahaan-perusahaan sektor property, real estate, and building construction yang terdaftar di Bursa Efek Indonesia pada periode September 2015 - September 2016.

Populasi penelitian ini adalah seluruh perusahaan sektor property, real estate and building construction yang terdaftar di Bursa Efek Indonesia pada tahun 2016, yaitu sebanyak 67 perusahaan. Dengan pengambilan sampel seperti pada Tabel 3.
Tabel 3. Sampel Penelitian

\begin{tabular}{clc}
\hline No & \multicolumn{1}{c}{ Keterangan } & Jumlah \\
\hline 1 & $\begin{array}{l}\text { Perusahaan-perusahaan sektor property, real estate } \\
\text { and building construction yang terdaftar di Bursa }\end{array}$ & 67 \\
& $\begin{array}{l}\text { Efek Indonesia sampai dengan tahun 2016. } \\
2\end{array}$ & $\begin{array}{l}\text { Perusahaan-perusahaan tidak memiliki data } \\
\text { lengkap dan tidak konsisten berada di sektor } \\
\text { penelitian }\end{array}$ \\
3 & $\begin{array}{l}\text { Perusahaan-perusahaan tersebut melakukan } \\
\text { corporate action seperti right issue, stock dividend, } \\
\text { cash dividend, dan lain sebagainya. }\end{array}$ \\
\hline \multicolumn{3}{c}{ Jumlah Sampel Penelitian } \\
\hline
\end{tabular}

Dalam metode penelitian kuantitatif, teknik analisis data menggunakan statistik yang sudah tersedia.

Menentukan Event periode, event periode yang digunakan dalam penelitian ini adalah selama 11 hari. Meliputi 5 hari sebelum terjadinya peristiwa, 1 hari saat peristiwa (event date), dan 5 hari sesudah peristiwa.

Menghitung Actual Return, untuk menghitung actual return dibutuhkan data harga saham atau closing price untuk saham masing-masing perusahaan, rumus untuk menghitung actual return adalah:

$$
\mathrm{R}_{\mathrm{i}, \mathrm{t}}=\left(\mathrm{P}_{\mathrm{i}, \mathrm{t}}-\mathrm{P}_{\mathrm{i}, \mathrm{t}-\mathrm{l}}\right) / \mathrm{P}_{\mathrm{i}, \mathrm{t}-\mathrm{1}}
$$

Keterangan:

$\mathrm{R}_{\mathrm{i}, \mathrm{t}}=$ return aktual yang terjadi untuk sekuritas i pada periode peristiwa $t$

$\mathrm{P}_{\mathrm{i}, \mathrm{t}}=$ harga saham harian sekuritas i pada periode ke $\mathrm{t}$

$\mathrm{P}_{\mathrm{i}, \mathrm{t}-\mathrm{l}}=$ harga saham harian sekuritas i pada periode sehari sebelum periode $t$

Menghitung Expected Return, penelitian ini menggunakan market-adjusted model sehingga tidak perlu ada periode estimasi dan data yang dibutuhkan untuk menghitung return eskpektasi adalah data harian indeks saham yang digunakan, yaitu indeks saham sektor property, real estate and building construction. Rumus untuk menghitung expected return adalah:

$$
\mathrm{RMj}=\left(\mathrm{IHSG}_{\mathrm{j}}-\mathrm{IHSG}_{\mathrm{j}-1}\right) / \mathrm{IHSG}_{\mathrm{j}-1}
$$

Keterangan:

$\mathrm{IHSG}_{\mathrm{j}}=$ nilai IHSG pada periode $\mathrm{j}$

$\mathrm{IHSG}_{\mathrm{j}-1}=$ nilai IHSG pada periode satu hari sebelum periode $\mathrm{j}$

Menghitung Abnormal return, menghitung abnormal return menggunakan market-adjusted model diperlukan actual return dan expected return pada periode tersebut. Rumus untuk menghitungnya adalah: 


$$
\mathrm{AR}_{\mathrm{i}, \mathrm{t}}=\mathrm{R}_{\mathrm{i}, \mathrm{t}}-\mathrm{E}\left[\mathrm{R}_{\mathrm{i}, \mathrm{t}}\right]
$$

Keterangan:

$\mathrm{AR}_{\mathrm{i}, \mathrm{t}} \quad=$ tingkat return tidak normal (abnormal return) sekuritas i pada periode peristiwa $t$

$\mathrm{R}_{\mathrm{i}, \mathrm{t}} \quad=$ return aktual (actual return) sekuritas i pada periode peristiwa $\mathrm{t}$

$E\left[R_{i,}\right]=$ return yang diharapkan (expected return) sekuritas i pada periode t dengan menggunakan model keseimbangan

Menghitung Trading volume activity, perbandingan jumlah saham perusahaan yang diperdagangkan dengan keseluruhan jumlah saham beredar selama periode penelitian menurut Foster merupakan cara untuk melakukan perhitungan trading volume activity. Rumus untuk menghitung trading volume activity adalah:

$$
\text { TVA }_{\mathrm{it}}=\frac{\begin{array}{c}
\text { jumlah saham perusahaan i yang di } \\
\text { perdagangkan pada periode ke-t }
\end{array}}{\begin{array}{c}
\text { jumlah saham perusahaan i yang } \\
\text { beredar pada periode ke-t }
\end{array}}
$$

Hipotesis penelitian ini, yaitu: (1) Terdapat perbedaan signifikan pada abnormal return sebelum dan sesudah peristiwa pengumuman paket kebijakan ekonomi jilid 1, 5, 7, 11 dan 13, (2) Terdapat perbedaan signifikan pada trading volume activity sebelum dan sesudah peristiwa pengumuman paket kebijakan ekonomi jilid 1, 5, 7, 11 dan 13.

Tingkat signifikansi $(\alpha)$ yang digunakan untuk pengujian adalah $5 \%$. Hasil uji normalitas menunjukkan data berdistribusi normal kemudian uji statistik paired sample t-test.

\section{HASIL}

Hasil analisis deskriptif average abnormal return dan average trading volume activity ditunjukkan pada Tabel 4.

Tabel 5. Hasil Uji Statistik Deskriptif Average Abnormal Return

\begin{tabular}{lccccc}
\hline \multicolumn{1}{c}{ Event } & $\mathrm{N}$ & $\begin{array}{c}\text { Mini- } \\
\text { mum }\end{array}$ & $\begin{array}{c}\text { Maxi- } \\
\text { mum }\end{array}$ & Mean & $\begin{array}{c}\text { Std. } \\
\text { Deviation }\end{array}$ \\
\hline Jilid 1 & 11 & -.014578 & .019295 & .00189673 & .009580192 \\
Jilid 5 & 11 & -.009495 & .013284 & .00003646 & .006217761 \\
Jilid 7 & 11 & -.009848 & .008653 & .00075200 & .005703017 \\
Jilid 11 & 11 & -.013059 & .006295 & -.00258209 & .006751565 \\
Jilid 13 & 11 & -.017841 & .011716 & -.00221345 & .008132591 \\
Valid N & 11 & & & & \\
(listwise) & & & & & \\
\hline
\end{tabular}

Sumber: Output SPSS 20 (olah data penulis, 2017)

Tabel 5 menunjukkan nilai tertinggi dan terendah average abnormal return saham-saham yang terdapat di sektor property, real estate and building contruction pada waktu sebelum dan sesudah peristiwa. Pada waktu penerbitan paket kebijakan ekonomi jilid 1, nilai average abnormal return tertinggi adalah 0.019295 atau $1.9295 \%$ yang berada tepat pada waktu peristiwa (t0). Sedangkan nilai terendahnya sebesar -0.014578 atau $-1.4578 \%$ yang berada pada waktu empat hari setelah peristiwa $(\mathrm{t}+4)$.

Tabel 6. Hasil Uji Statistik Deskriptif Average Trading Volume Activity

\begin{tabular}{lccccc}
\hline & $\mathrm{N}$ & $\begin{array}{c}\text { Mini- } \\
\text { mum }\end{array}$ & $\begin{array}{c}\text { Maxi- } \\
\text { mum }\end{array}$ & Mean & $\begin{array}{c}\text { Std. } \\
\text { Deviation }\end{array}$ \\
\hline Jilid 1 & 11 & .002706 & .006885 & .00476815 & .001267637 \\
\hline Jilid 5 & 11 & .002715 & .005895 & .00413188 & .001065719 \\
\hline Jilid 7 & 11 & .001594 & .003781 & .00282022 & .000695518 \\
\hline Jilid 11 & 11 & .002418 & .004128 & .00329702 & .000519677 \\
\hline Jilid 13 & 11 & .002670 & .005376 & .00366899 & .000922567 \\
\hline Valid N & 11 & & & & \\
(listwise) & & & & \\
\hline Sumber: Output SPSS 20 (olah data penulis, 2017) &
\end{tabular}

Tabel 6 menunjukkan nilai tertinggi dan terendah average trading volume activity saham-saham yang terdapat di sektor property, real estate and building contruction pada waktu sebelum dan sesudah. Pada waktu penerbitan paket kebijakan ekonomi jilid 1, nilai average trading volume activity tertinggi adalah 0.006885 atau $0.6885 \%$ yang berada tepat pada waktu peristiwa (t0). Sedangkan nilai terendahnya sebesar 0.002706 atau $0.2706 \%$ yang berada pada waktu dua hari sebelum peristiwa ( $\mathrm{t}-2)$.

Normalitas data abnormal return dan trading volume activity saham dalam indeks sektor property, real estate and building construction sebelum dan sesudah peristiwa penerbitan paket kebijakan ekonomi jilid 1, 5,7, 11 dan 13 menggunakan One Sample Kolmogorov Sminorv Test.

Hasil pengujian normalitas data abnormal return dan trading volume activity saham dalam indeks sektor property, real estate and building construction sebelum dan sesudah peristiwa penerbitan paket kebijakan ekonomi jilid 1, 5, 7, 11 dan 13 menunjukkan data average abnormal return dan berdistribusi dengan normal karena memiliki probabilitas dengan signifikansi lebih dari 0,05 .

Pengujian hipotesis menggunakan uji statistik paired sample t-test dengan tingkat signifikansi sebesar 0,05 menunjukkan tidak terdapat perbedaan signifikan pada abnormal return sebelum dan sesudah penerbitan paket kebijakan ekonomi jilid 1. Hal serupa juga terjadi pada sebelum dan sesudah penerbitan paket kebijakan ekonomi jilid 5, 7, dan 13. Sedangkan hasil lain ditunjukkan oleh pasangan keempat, yaitu sebelum dan sesudah peristiwa penerbitan paket kebijakan ekonomi jilid 11 yang secara statistik terdapat perbedaan signifikan (Tabel 7). 
Hasil pengujian perbedaan average trading volume activity ditunjukkan oleh Tabel 8. Pada pasangan pertama, yaitu sebelum dan sesudah penerbitan paket kebijakan ekonomi jilid 1, secara statistik tidak terdapat perbedaan yang signifikan. Hal serupa juga terjadi pada penerbitan paket kebijakan ekonomi jilid 5, 7, 11 dan 13.

\section{PEMBAHASAN}

Hasil penelitian ini memiliki kesamaan dengan penelitian terdahulu mengenai informasi-informasi eksternal oleh I Made dan Ida Bagus (2015) menunjukkan tidak terdapat perbedaan abnormal return yang signifikan sebelum dan sesudah pengumuman peristiwa pemilu legislatif tahun 2014. Sama halnya dengan penelitian oleh Nurbaity dan Syarifah (2017), hasil dari pengujian reaksi pasar terhadap peristiwa pengumuman paket kebijakan ekonomi jilid II menggunakan one sample t-test pasar bereaksi sebelum terjadinya peristiwa tetapi tidak bereaksi pada saat dan sesudah peristiwa. Sedangkan pada pengujian paired sample t-test AAR dan ATVA tidak menunjukkan perbedaan yang signifikan.

Pada waktu peristiwa penerbitan paket kebijakan ekonomi jilid 5, nilai average abnormal return tertinggi adalah 0.013284 atau $1.3284 \%$ yang berada tiga hari sebelum peristiwa (t-3). Sedangkan nilai terendahnya terdapat pada -0.009495 atau $-0.9495 \%$ yang terjadi pada waktu empat hari setelah peristiwa $(\mathrm{t}+4)$. Average abnormal return pada peristiwa penerbitan paket kebijakan ekonomi 7 memiliki nilai tertinggi sebesar 0.008653 atau $0,8653 \%$ yang terjadi tepat satu hari setelah peristiwa $(t+1)$. Sedangkan nilai terendahnya sebesar -0.009848 atau $-0.9848 \%$ pada waktu peristiwa terjadi (t0).

Peristiwa penerbitan paket kebijakan ekonomi jilid 11 memberikan average abnormal return dengan nilai tetingginya sebesar 0.006295 atau $0.6295 \%$ yang terjadi tepat saat peristiwa ( $\mathrm{t} 0)$. Sedangkan nilai terendahnya sebesar -0.013059 atau sebesar $-1.3059 \%$ pada waktu empat hari setelah peristiwa $(t+4)$. Pada waktu peristiwa penerbitan paket kebijakan ekonomi jilid 13 nilai average abnormal return tertinggi adalah 0.011716 atau $1.1716 \%$ yang terjadi pada empat hari setelah peristiwa terjadi $(\mathrm{t}+4)$. Sedangkan nilai terendahnya sebesar -0.017841 atau $-1.7841 \%$ yang terjadi pada tiga hari sebelum peristiwa $(\mathrm{t}-3)$.
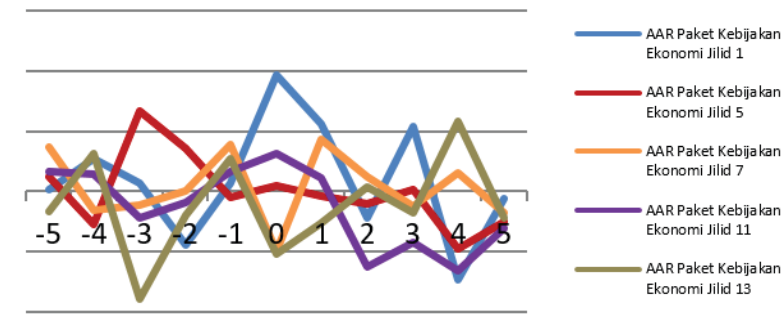

Gambar 3. Grafik Average Abnormal Return
Berdasarkan Gambar 3, dapat dilihat bahwa selama penerbitan paket kebijakan ekonomi jilid 1, 5, 7, 11 dan 13 terjadi fluktuasi average abnormal return pada saham-saham di indeks sektor property, real estate and building construction. Paket kebijakan ekonomi jilid 1 menunjukkan abnormal return yang positif terbesar pada waktu penerbitan paket kebijakan ekonomi jilid 1 sebesar 0,019295, sedangkan average abnormal return terendah terjadi tiga hari sebelum (h-3) penerbitan paket kebijakan ekonomi jilid 13 dengan nilai average abnormal return sebesar - 0,017841 .

Pada waktu peristiwa penerbitan paket kebijakan ekonomi jilid 5, nilai average trading volume activity tertinggi adalah 0.005895 atau $0.5895 \%$ yang berada satu hari sebelum peristiwa (t-1). Sedangkan nilai terendahnya terdapat pada -0.002715 atau $0.2715 \%$ yang terjadi pada waktu empat hari sebelum peristiwa $(\mathrm{t}-4)$. Average trading volume activity pada peristiwa penerbitan paket kebijakan ekonomi 7 memiliki nilai tertinggi sebesar 0.003781 atau $0,3781 \%$ yang terjadi dua hari sebelum peristiwa $(\mathrm{t}-2)$. Sedangkan nilai terendahnya sebesar -0.001594 atau $0.1594 \%$ pada waktu tiga hari setelah peristiwa terjadi $(\mathrm{t}+3)$.

Peristiwa penerbitan paket kebijakan ekonomi jilid 11 memberikan average trading volume activity dengan nilai tetingginya sebesar 0.004128 atau $0.4128 \%$ yang terjadi saat empat hari sebelum peristiwa (t-4). Sedangkan nilai terendahnya sebesar 0.002418 atau sebesar $0.2418 \%$ pada waktu dua hari sebelum peristiwa (t-2). Pada waktu peristiwa penerbitan paket kebijakan ekonomi jilid 13 nilai average trading volume activity tertinggi adalah 0.005376 atau $0.5376 \%$ yang terjadi pada tiga hari setelah peristiwa terjadi $(\mathrm{t}+3)$. Sedangkan nilai terendahnya sebesar 0.002670 atau $0.267 \%$ yang terjadi pada empat hari sebelum peristiwa (t-4).
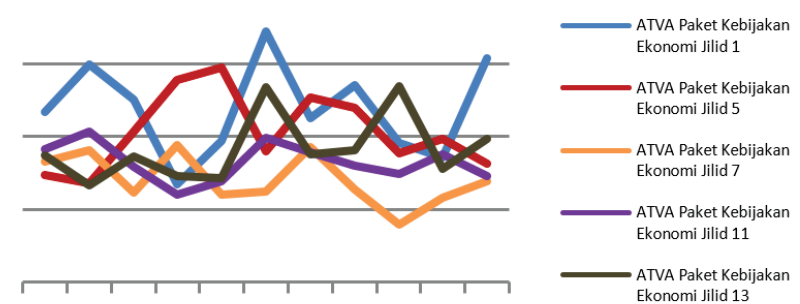

$\begin{array}{lllllllllll}-5 & -4 & -3 & -2 & -1 & 0 & 1 & 2 & 3 & 4 & 5\end{array}$

Gambar 4. Grafik Average Trading Volume Activity

Berdasarkan Gambar 4, dapat dilihat bahwa selama penerbitan paket kebijakan ekonomi jilid 1, 5, 7, 11 dan 13 terjadi fluktuasi average trading volume activity pada saham-saham di indeks sektor property, real estate and building construction. Paket kebijakan ekonomi jilid 1 menunjukkan trading volume yang terbesar pada waktu penerbitan paket kebijakan ekonomi jilid 1 sebesar 0,006885 , sedangkan average trading volume activity terendah terjadi tiga hari sesudah $(\mathrm{h}+3)$ penerbitan 
paket kebijakan ekonomi jilid 13 dengan nilai average abnormal return sebesar $-0,017841$.

Uji statistik paired sample t-test menunjukkan hasil bahwa tidak terdapat perbedaan yang signifikan pada average abnormal return saham-saham pada indeks sektor property, real estate and building construction pada waktu sebelum dan sesudah paket kebijakan ekonomi jilid 1, 5, 7 dan 13.

Namun hasil berbeda di dapat pada waktu sebelum dan sesudah penerbitan paket kebijakan ekonomi jilid 11 yang menunjukkan terdapat perbedaan signifikan sebelum dan sesudah peristiwa penerbitan. Hal tersebut terjadi karena ada salah satu isi paket kebijakan ekonomi jilid 11 yaitu menerbitkan Dana Investasi Real estate (DIRE) dengan biaya yang relatif rendah dan untuk menunjang percepatan pembangunan infrastruktur sesuai program jangka menengah nasional tahun 20152019. Lebih lengkapnya dari DIRE tersebut dijabarkan sebagai berikut: (1) Penerbitan regulasi fasilitas Pajak Penghasilan final berupa pemotongan tarif hingga $0,5 \%$ dari tarif normal $5 \%$ kepada perusahaan yang menerbitkan DIRE. (2) Penerbitan regulasi penurunan tarif BPHTB dari maksimum 5\% menjadi $1 \%$ bagi tanah dan bangunan yang menjadi aset DIRE. (3) Penerbitan Peraturan Daerah (Perda) bagi daerah yang berminat untuk mendukung pelaksanaan DIRE di daerahnya.

Kemudian uji statistik paired sample t-test menunjukkan hasil bahwa tidak terdapat perbedaan yang signifikan pada average trading volume activity saham-saham pada indeks sektor property, real estate and building construction pada waktu sebelum dan sesudah paket kebijakan ekonomi jilid 1, 5, 7, 11 dan 13.

Hal tersebut berarti investor sebagai pelaku pasar modal tidak menganggap peristiwa tersebut sebagai informasi yang memberikan efek dalam trading volume activity karena investor tidak hanya melakukan analisis teknikal saja, melainkan menggunakan analisis fundamental yang melihat kinerja perusahaan.

\section{KESIMPULAN}

Berdasarkan pengujian dan pembahasan selama penerbitan paket kebijakan ekonomi jilid 1, 5, 7, 11 dan 13 terjadi fluktuasi average abnormal return. Average abnormal return terbesar terjadi pada waktu penerbitan paket kebijakan ekonomi jilid 1, sedangkan terendah terjadi tiga hari sebelum (h-3) penerbitan paket kebijakan ekonomi jilid 13.

Kemudian selama penerbitan paket kebijakan ekonomi jilid 1, 5, 7, 11 dan 13 juga terjadi fluktuasi average trading volume activity. Average trading volume terbesar terjadi pada waktu penerbitan paket kebijakan ekonomi jilid 1, sedangkan terendah terjadi tiga hari sesudah $(\mathrm{h}+3)$ penerbitan paket kebijakan ekonomi jilid 13.

Tidak terdapat perbedaan signifikan pada abnormal return dan average trading volume activity saham indeks sektor property, real estate and building construction periode September 2015 - September 2016 sebelum dan sesudah peristiwa penerbitan paket kebijakan ekonomi jilid 1, 5, 7 dan 13. Namun terdapat perbedaan signifikan abnormal return sebelum dan sesudah peristiwa penerbitan paket kebijakan ekonomi jilid 11. Pada trading volume activity tidak terjadi perbedaan signifikan sektor property, real estate and building construction periode September 2015 - September 2016 sebelum dan sesudah peristiwa penerbitan paket kebijakan ekonomi jilid 1, 5, 7, 11 dan 13.

\section{DAFTAR PUSTAKA}

Abbas, Fauzie Pradita. 2017. BEI: Jumlah Investor Baru Pasar Modal Naik 23,47\%. [online]. http://jabar. tribunnews.com/2017/02/20/bei-jumlah-investorbaru-pasar-modal-naik-2347. [13 Maret 2017]

Aliya, Angga. 2015. IHSG Kompak Melompat Bareng Bursa Asia. [online]. https://finance.detik. com/bursa-dan-valas/d-3051843/ihsg-kompakmelompat-bareng-bursa-asia. [4 Oktober 2017]

Deny, Septian. 2017. Jokowi Umumkan Paket Kebijakan Ekonomi ke-16 pada 31 Agustus. [online]. http://bisnis.liputan6.com/read/3076979/ jokowi-umumkan-paket-kebijakan-ekonomi-ke-16pada-31-agustus. [15 September 2017]

Dewi, Gusti Ayu Surya Rosita, Dewa Gede Wirama, Ni Ketut Rasmini.2017. Reaksi Pasar Atas Pengumuman Paket Kebijakan Ekonomi X Tentang Daftar Negatif Investasi. Jurnal Ilmiah Akuntansi dan Bisnis, Vol. 12 No. 2 Juli, 104-114.

Fama, Eugene F. 1970. Efficient Capital Market: A Review of Theory and EMpirical Work. The Journal of Finance. Vol. 25 No. 2, 383-417.

Hartono, Jogiyanto. 2017. Teori Portofolio dan Analisis Invetasi. Yogyakarta: BPFE-Yogyakarta.

Mahaputra, I Made Dwi, Ida Bagus Anom Purbawangsa. 2015. Pengaruh Peristiwa Pemilu Legislatif 2014 Terhadap Perolehan Abnormal return Saham LQ 45 di Bursa Efek Indonesia. E-Jurnal Manajemen Unud, Vol. 4, No. 5, 1406-1421.

Muzakir, Nurbaity, Syarifah Rahmawati. 2017. Reaksi Pasar Modal Indonesia Terhadap Peristiwa Pengumuman Paket Kebijakan Ekonomi Jilid II. Jurnal Ilmu Manajemen Ekonomi Manajemen (JIMEKM) 1, 188-202.

Nazir, Mian Zajid, et al. 2014. Impact of political events on market returns: empirical evidence from Pakistan. Journal of Economic and Administrative Sciences, Vol. 30 Issue: 1, 60-78.

Putri, Syafitri Riezkya. 2016. Analisis Perbedaan Abnormal return dan Volume Perdagangan Sebelum dan Sesudah Pengumuman Paket Kebijakan Ekonomi Jilid II (Studi Kasus Pada Kelompok Saham LQ45 di BEI Tahun 2015). e-Proceeding of Management : Vol3, No3 December, 2808. 
Rica Syafitri, Wiwik Tiswiyanti, Fitrini Mansur. 2012. Dampak Pergantian Menteri Keuangan RI Tahun 2010 Terhadap Abnormal return Perusahaan Perbankan yang Terdaftar di BEI. e-Jurnal BINAR Akuntansi Vol. 1 No. 1, September.

Samsul, Mohamad. 2006. Pasar Modal dan Manajemen Portofolio. Jakarta: Erlangga.

Tay, Liang-Mui, et al. 2016. The effect of white collar crime announcement on stock price performance: Evidence from Malaysian stock market. Journal of Financial Crime, Vol. 23 Issue: 4, 1126-1139.

Wardani, Devi Kusuma. 2004. Analisis Reaksi Pasar Modal Indonesia Sebagai Dampak dari Peristiwa Politik (Political Event) Pemilu 5 April 2004 pada Saham LQ-45. Skripsi Jurusan Manajemen Fakultas Ekonomi Universitas Brawijaya Malang.

Tabel 4. Hasil Perhitungan Average Abnormal Return dan Trading Volume Activity

\begin{tabular}{cccccccccccc}
\hline \multirow{2}{*}{ HARI } & \multicolumn{3}{c}{ JILID 1 } & \multicolumn{2}{c}{ JILID 5 } & \multicolumn{2}{c}{ JILID 7 } & \multicolumn{2}{c}{ JILID 11 } & \multicolumn{3}{c}{ JILID 13 } \\
\cline { 2 - 12 } & AR & TVA & AR & TVA & AR & TVA & AR & TVA & AR & TVA \\
\hline-5 & 0,000299 & 0,004685 & 0,002487 & 0,002949 & 0,007308 & 0,003315 & 0,003261 & 0,003649 & $-0,003207$ & 0,003481 \\
-4 & 0,005352 & 0,005979 & $-0,005500$ & 0,002715 & $-0,003017$ & 0,003621 & 0,002793 & 0,004128 & 0,006236 & 0,002670 \\
-3 & 0,001415 & 0,005006 & 0,013284 & 0,004135 & $-0,002192$ & 0,002478 & $-0,004298$ & 0,003170 & $-0,017841$ & 0,003467 \\
-2 & $-0,008847$ & 0,002706 & 0,007167 & 0,005567 & $-0,000002$ & 0,003781 & $-0,001828$ & 0,002418 & $-0,003883$ & 0,002907 \\
-1 & 0,001487 & 0,003896 & $-0,000909$ & 0,005895 & 0,007685 & 0,002405 & 0,003259 & 0,002774 & 0,005381 & 0,002856 \\
0 & 0,019285 & 0,006885 & 0,000994 & 0,003586 & $-0,009848$ & 0,002482 & 0,006295 & 0,003972 & $-0,010310$ & 0,005368 \\
1 & 0,011165 & 0,004506 & $-0,000833$ & 0,005072 & 0,008653 & 0,003713 & 0,002185 & 0,003557 & $-0,005191$ & 0,003523 \\
2 & $-0,004399$ & 0,005398 & $-0,002081$ & 0,004801 & 0,002491 & 0,002536 & $-0,012407$ & 0,003204 & 0,000788 & 0,003633 \\
3 & 0,010776 & 0,003818 & 0,000313 & 0,003532 & $-0,002440$ & 0,001594 & $-0,008484$ & 0,002978 & $-0,003599$ & 0,005376 \\
4 & $-0,014578$ & 0,003430 & $-0,009495$ & 0,003939 & 0,003058 & 0,002332 & $-0,013059$ & 0,003504 & 0,011716 & 0,003127 \\
5 & $-0,001101$ & 0,006142 & $-0,005026$ & 0,003261 & $-0,003424$ & 0,002764 & $-0,006120$ & 0,002913 & $-0,004438$ & 0,003950 \\
\hline
\end{tabular}

Tabel 7. Hasil Uji Beda Average Abnormal Return Menggunakan Paired Sample T-Test

Paired Samples Test

\begin{tabular}{|c|c|c|c|c|c|c|c|c|c|}
\hline & & \multicolumn{5}{|c|}{ Paired Differences } & \multirow{3}{*}{$\mathrm{t}$} & \multirow{3}{*}{$\mathrm{df}$} & \multirow{3}{*}{$\begin{array}{c}\text { Sig. } \\
\text { (2-tailed) }\end{array}$} \\
\hline & & \multirow{2}{*}{ Mean } & \multirow{2}{*}{ Std. Deviation } & \multirow{2}{*}{$\begin{array}{l}\text { Std. Error } \\
\text { Mean }\end{array}$} & \multicolumn{2}{|c|}{$\begin{array}{l}\text { 95\% Confidence Interval of the } \\
\text { Difference }\end{array}$} & & & \\
\hline & & & & & Lower & Upper & & & \\
\hline $\begin{array}{l}\text { Pair } \\
1\end{array}$ & $\begin{array}{l}\text { sebelum_1- } \\
\text { sesudah_1 }\end{array}$ & -.000431400 & .009211295 & .004119417 & -.011868734 & .011005934 & -.105 & 4 & .922 \\
\hline $\begin{array}{l}\text { Pair } \\
2\end{array}$ & $\begin{array}{l}\text { sebelum_5- } \\
\text { sesudah_5 }\end{array}$ & .006730200 & .008047558 & .003598977 & -.003262163 & .016722563 & 1.870 & 4 & .135 \\
\hline $\begin{array}{l}\text { Pair } \\
3\end{array}$ & $\begin{array}{l}\text { sebelum_7- } \\
\text { sesudah_7 }\end{array}$ & .000288800 & .006414145 & .002868493 & -.007675413 & .008253013 & .101 & 4 & .925 \\
\hline $\begin{array}{l}\text { Pair } \\
4\end{array}$ & $\begin{array}{l}\text { sebelum_11- } \\
\text { sesudah_11 }\end{array}$ & .008214400 & .005622267 & .002514354 & .001233434 & .015195366 & 3.267 & 4 & .031 \\
\hline $\begin{array}{l}\text { Pair } \\
5\end{array}$ & $\begin{array}{l}\text { sebelum_13- } \\
\text { sesudah } 13\end{array}$ & -.002518000 & .011667170 & .005217717 & -.017004706 & .011968706 & -.483 & 4 & .655 \\
\hline
\end{tabular}

Sumber: Output SPSS 20 (olah data penulis, 2017) 
Tabel 8. Hasil Uji Beda Average Trading Volume Activity Menggunakan Paired Sample T-Test

Paired Samples Test

\begin{tabular}{|c|c|c|c|c|c|c|c|c|c|}
\hline & & \multicolumn{5}{|c|}{ Paired Differences } & \multirow{3}{*}{$\mathrm{t}$} & \multirow{3}{*}{ df } & \multirow{3}{*}{$\begin{array}{c}\text { Sig. } \\
\text { (2-tailed) }\end{array}$} \\
\hline & & \multirow[t]{2}{*}{ Mean } & \multirow[t]{2}{*}{ Std. Deviation } & \multirow{2}{*}{$\begin{array}{l}\text { Std. Error } \\
\text { Mean }\end{array}$} & \multicolumn{2}{|c|}{$\begin{array}{l}\text { 95\% Confidence Interval of the } \\
\text { Difference }\end{array}$} & & & \\
\hline & & & & & Lower & Upper & & & \\
\hline $\begin{array}{l}\text { Pair } \\
1\end{array}$ & $\begin{array}{l}\text { sebelum_1- } \\
\text { sesudah_1 }\end{array}$ & -.000204600 & .001335848 & .000597409 & -.001863274 & .001454074 & -342 & 4 & .749 \\
\hline $\begin{array}{l}\text { Pair } \\
2\end{array}$ & $\begin{array}{l}\text { sebelum_5- } \\
\text { sesudah_5 }\end{array}$ & .000131200 & .002163585 & .000967585 & -.002555246 & .002817646 & .136 & 4 & .899 \\
\hline $\begin{array}{l}\text { Pair } \\
3\end{array}$ & $\begin{array}{l}\text { sebelum_7- } \\
\text { sesudah_7 }\end{array}$ & .000532200 & .000855772 & .000382713 & -.000530381 & .001594781 & 1.391 & 4 & .237 \\
\hline $\begin{array}{l}\text { Pair } \\
4\end{array}$ & $\begin{array}{l}\text { sebelum_11- } \\
\text { sesudah_11 }\end{array}$ & -.000003400 & .000724183 & .000323864 & -.000902592 & .000895792 & -.010 & 4 & .992 \\
\hline $\begin{array}{l}\text { Pair } \\
5\end{array}$ & $\begin{array}{l}\text { sebelum_13- } \\
\text { sesudah_13 }\end{array}$ & -.000845600 & .000748908 & .000334922 & -.001775492 & .000084292 & -2.525 & 4 & .065 \\
\hline
\end{tabular}

Sumber: Output SPSS 20 (olah data penulis, 2017) 